\title{
Legal Remedies in Asylum and Immigration Law: The Balance Between Effectiveness and Procedural Autonomy? ${ }^{1}$
}

\author{
Alžbeta Králová \\ Masaryk University, Faculty of Law, Czech Republic \\ alzbeta.kralova@mail.muni.cz
}

\section{ABSTRACT}

The paper tackles a widely discussed but still rather under-researched area of asylum and immigration law, more precisely its procedural aspects and its interactions within the public administration and administrative judiciary. It contributes to the debate about the Europeanization of public administration within the specific context of asylum and immigration law. The purpose of the paper is to examine the influence of European Union law on the legal regulation of administrative and judicial review of decisions rendered in asylum and immigration procedures. The research is based on an in-depth analysis of the dynamics of amendments and the motivation of national legislation while adopting new procedural rules in the above-mentioned areas on the case of the Czech Republic (based on the description and analysis of the legal regulation, explanatory memoranda and the case law, supplemented with certain comparative aspects). The procedural autonomy principle gets increasingly limited by other principles, namely the effectiveness principle and the principle of effective judicial protection. The paper therefore focuses on the margin of appreciation left to the national legislator: it determines whether the principle of procedural autonomy keeps the real relevancy while harmonising the asylum and immigration law and what is the influence of tensions between the aforementioned principles. The research shows that the legislator still maintains quite a wide degree of margin of appreciation in the administrative and judicial review of asylum and immigration decisions (apart from the visa procedures). However, a broadening of the interpretation of the effective judicial protection principle as provided by Article 47 of the Charter of Fundamental Rights of the EU decreases the scope of procedural autonomy and has the potential to influence not only individual legal remedy, but also the system of administrative or judicial remedies as such. Besides the overall findings related to the influence of European Union law on the review in asylum and immigration procedures, the article tackles numerous practical implications of amendments based in European Union law and practical challenges for the administrative and judicial review in concerned area of law. The paper provides a reaction to tensions coming from the need to find the balance between the obliga-

1 This article is a revised version of the paper entitled 'Legal remedies in asylum and immigration law: the balance between effectiveness and procedural autonomy?', presented at the EGPA conference, Toulouse, 26-28 August 2015. The EGPA contributions are not publicly available. 
tion to provide an effective remedy and between the autonomy of Member States and their attempts to preserve national procedural traditions and specificities within the system of administrative and judicial review. It is original by its overall view on the problematic of remedies in asylum and immigration law and by a new perspective of interactions between national legislation and European Union law. Although the research is limited to the case study of the Czech Republic, certain aspects apply to other Member States with similarities within their system of administrative and judicial review.

Keywords: asylum procedures, effective remedy, immigration procedures, procedural autonomy, judicial review

$J E L: K 37$

\section{Introduction}

Procedural regulation is traditionally perceived as an area influenced by European Union law only to a limited extent. The principle of procedural autonomy, in general, leaves the procedures and remedies before the national courts to the national legal regulation. However, the need to guarantee the effectiveness of legal remedies causes tendencies leading to a stronger harmonisation not only for the substantive law but also for the procedural rules. These tendencies are also present in the area of asylum and immigration law, therefore more and more institutes of asylum and immigration procedure change due to European Union law and due to the fact that the definition of the effectiveness of the remedies becomes more specific and more uniform.

Recent developments, influenced mostly by the interpretation of Article 47 of the Charter of Fundamental Rights of the EU, show that European Union law affects not only the extent of the judicial review, but it also has the potential to influence the architecture of the administrative judiciary. In the Czech Republic, this is the case of debates regarding meeting the requirements laid down in the recast of Procedures Directive ${ }^{2}$ (or Procedures Regulation, if adopted ${ }^{3}$ ), especially the implementation of a full and ex nunc judicial review in asylum cases. Another example is the long-lasting debate about the necessity of a judicial review in visa procedures.

The above-mentioned development raises numerous questions regarding the motivation of amendments of domestic remedies in asylum and immigration law, regarding the relation of the the national legislator and European Union law, the balance between the implementation of the principle of effectiveness of judicial protection and the principle of procedural autonomy, which seems to be more and more limited. The main research question is therefore to what extent the European Union law influences the legal regulation of

2 Directive 2013/32/EU, OJ L 180, 29. 6. 2013, p. 60-95.

3 See proposal for a regulation of the European Parliament and of the Council establishing a common procedure for international protection in the Union and repealing Directive 2013/32/ EU COM(2016) 467 final. 
remedies in asylum and immigration procedures. This research question is followed by more specific questions: what motivates the legislator to amend the legal regulation of remedies in asylum and immigration law, what is the extent of margin of appreciation given to the national legislator, which amendments are related to the principle of effective judicial protection and what is the impact of such amendments on the system of administrative review and on the administrative judiciary. The research tries to answer these questions on the case of the Czech Republic by means of an in-depth analysis of national legislation and of the motivation of legislative changes (based mainly on explanatory memoranda) and the related case law, using also limited comparative aspects. Apart from the existing state of legislation, we must deal with the potential changes of remedial measures in asylum and immigration law, their impact on the administrative judiciary (not only in the Czech Repub(ic) and the possible limitation of such changes with regard to the procedural autonomy principle. The research focuses on remedies in asylum procedures, visa procedures, adminstrative expulsion and administrative detention procedures, i. e. the key types of procedures that are in some extent harmonised by European Union law and for which there is a specific remedy available in national legal order ${ }^{4}$.

We are aware of the fact that the asylum and immigration law are now facing enormous systemic challenges. Focusing on the aforementioned, rather technical aspects of asylum and immigration procedures without solving (or at least trying to solve) the crucial problems resulting from migration flows may seem pointless. However, the question of balance between the need to guarantee an effective remedy and the need to respect the national procedural specifics is more relevant than ever as we are getting closer to not only "harmonised", but to truly "common" asylum procedures.

\section{Principle of Procedural Autonomy and Its Limitations}

The principle of procedural autonomy was defined, as many other European Union law principles, in the case law of the Court of Justice of the European Union ("CJEU") ${ }^{6}$ in the following manner:

4 The paper does not discuss, for example, the remedy against a transfer decision set out in Article 27 of the Regulation No. 604/2013 establishing the criteria and mechanisms for determining the Member State responsible for examining an application for international protection lodged in one of the Member States by a third-country national or a stateless person (Dublin III) as the review of such decision makes an integral part of a review against the decision on inadmissibility of an application for international protection (i. e. there is no specific remedy for a transfer decision). Although the CJEU decided several interesting cases related to the need to provide an effective remedy against a transfer decision (for example judgments of 7 June 2016 C-63/15 Ghezelbash and C-155/15, Karim), they related more to the material scope of review (not to procedural aspects that could influence legal regulation in the Czech Republic) and they were reflected in the decision-making of the courts (see for example the judgment of Supreme Administrative Court of 12 September 2016, no. 5 Azs 195/2016).

5 Proposed Asylum Procedures Regulation aims, by choosing the form of a Regulation, which is directly applicable in all Member States, and by removing elements of discretion, at achieving a truly common asylum procedures across all Member States.

6 The reference to the "Court of Justice of the European Union" is used for both the European Court of Justice, as well as for the "Court of Justice of the European Union". 
"Accordingly, in the absence of Community rules on this subject, it is for the domestic legal system of each Member State to designate the courts having jurisdiction and to determine the procedural conditions governing actions at law intended to ensure the protection of the rights which citizens have from the direct effect of Community law, it being understood that such conditions cannot be less favourable than those relating to similar actions of a domestic nature."

The emphasis on the principle of procedural autonomy in the above-cited Rewe judgment was immediately complemented by important limitations defined by the principle of equivalence requiring not to discriminate between claims based on national law and claims arising out of EU law and the principle of effectiveness preventing the situation in which the national rules would make EU law enforcement impossible ${ }^{8}$ or excessively difficult ${ }^{9}$.

It is the principle of judicial protection, formulated once again in the case of the Court of Justice of the EU that provides even more intensive scrutiny of national procedural rules. In Johnson ${ }^{10}$, the Court of Justice stated:

"The requirement of judicial control stipulated by that article reflects a general principle of law which underlies the constitutional traditions common to the Member States. That principle is also laid down in Articles 6 and 13 of the European Convention for the Protection of Human Rights and Fundamental Freedoms [...] and as the Court has recognized in its decisions, the principles on which that Convention is based must be taken into consideration in Community law."

The Court of Justice of the EU, therefore, formulated a crucial principle which incorporated the principle of effective remedy and effective judicial protection stipulated by the European Convention for the Protection of Human Rights and Fundamental Freedoms into European Union law. Even though the Court of Justice recalled the importance of effective judicial protection on many occasions, including the cases in asylum and immigration matters, ${ }^{11}$ the principle became even more apparent and resonant after its "codification" by the Charter of Fundamental Rights of the EU in Article 47 and the reference to the principle in Article 19 of Treaty on European Union.

Despite the fact that both the principle of effectiveness from Rewe test and the principle of effective judicial protection (or effective remedy) work with the term "effectiveness", they are not interchangeable as their scope is different, although the opinions on their mutual relationship may differ. The principle of effective judicial protection may be seen as much wider, as it covers not only the access to European Union law enforcement but many different

7 Judgment of CJEU of 16 December 1976, C-33/76, Rewe v. Landwirtschaftskammer für das Saarland.

8 lbid.

9 Judgment of CJEU of 5 March 1996, C-46/93 and C-48/93, Joined Cases C-46/93 and C-48/93, Brasserie du pêcheur v. Bundesrepublik Deutschland a The Queen / Secretary of State for Transport, ex parte Factortame and others, par. 83.

10 Judgment of CJEU of 15 May 1986, 222/84, Johnston v. Chief Constable of the Royal Ulster Constabulary, par. 18.

11 See for example the judgment of the CJEU (Grand Chamber) of 16 November 2004, C-327/02, Panayotova and Others, the Court of Justice reminded the need of effective judicial scrutiny in the context of residence permit proceedings (see also Brouwer, 2007, pp. 75-76). 
aspects of fair trial, such as legal assistance, fair and public hearing, independent and impartial tribunal, etc. However, this does not necessarily mean that the principle of effectiveness is the subset of effective judicial protection. As pointed out by Sacha Prechal, both principles are driven by different rationales: while the effectiveness principle primarily aims to guarantee an effective application of substantive European Union law, the principle of effective judicial protection is linked to the fundamental access to the court and the idea of "Rechtstaat" (Prechal, 2011, p. 50). Their purposes may even seem to be contrasting as the effective judicial protection may sometimes limit the effectiveness of the protection provided by European Union law, instead of strengthening it (Safjan, 2014). The case law does not provide a completely clear answer on the mutual relation of the principles yet, the CJEU, however, seems to be testing the national procedural and remedial provisions against both principles in parallel. ${ }^{12}$

The limitations of the procedural autonomy principle could indicate a decreasing importance of autonomy and an increasing emphasis on the effectiveness as such or the effectiveness of judicial protection. However, opinions differ: while for example Sacha Prechal notes that despite the standardisation, the substance of judicial protection and the enforcement of Union law in the Member State, the national procedural autonomy remains the leading principle governing the application of Union law in national courts (Prechal, 2011, p. 31), Michal Bobek claims that there is no such thing as „procedural autonomy" of Member States because there are no areas that are "free" from any European Union law constraints uncontrolled by the Court of Justice (Bobek, 2011, p. 316). ${ }^{13}$ Which of these statements seems to be more relevant for the legal remedies in asylum and immigration law in the Czech Republic?

\section{Legal Remedies in Czech Asylum Law and Their Development}

The review of the decisions on international protection is entrusted to the administrative courts $n$ the Czech Republic. There are therefore no specialised tribunals or courts for asylum matters. An action against the decision of the Ministry of Interior on a matter of international protection is the first remedy available, there is no review by administrative organs themselves. To answer the question of how European Union law influences the procedural rules of an appeal system and to what extent the procedural autonomy of the national legislator is guaranteed, we need to focus on the legislative development of remedies in the asylum procedure and the motivation of the legislator which led him to the amendments. We have to look at the overview of the relevant provisions of Act No. 325/1999 Coll., the Asylum Act and Act No. 150/2002 Coll., Code of Administrative Justice, affecting the effectiveness of legal pro-

12 See also recent judgment of CJEU of 13 December 2017, C-403/16, El Hassani.

13 There is of course much wider spectrum of opinions on the interpretation and content of the procedural autonomy principle, a nice overview provides for example an article of Baghrizabehi (Baghrizabehi, 2016). 
tection in asylum matters, along with the explanation of the amendments (based on the explanatory memorandum of the amendment acts).

The first important amendment of the review of asylum decisions was related to the repeal of remonstrance and to the introducing of a direct access to the judicial protection (Act No. 2/2002 Coll., in force since 2002). Even though there was no reason indicated in the explanatory memorandum, there was an indisputable indirect effect of Council Resolution of 20 June 1995 on minimum guarantees for asylum procedures (see Pipková, 2011). Most of other amendments were related to the time-limits for bringing and action: firstly shortening of a time-limit for bringing an action to 30 days (Act No. 325/1999 Coll., in force since 2000), shortening of the time limit to 15 or 7 days (Act No. 217/2002 Coll.), shortening of time limits together with the deprivation of automatic suspensory effect of an appeal for few types of decisions (inadmissible applications) (Act No. 350/2005 Coll., in force since 2005), repeal of the 7-day time limit to lodge an action in case of manifestly unfounded application (decision of Constitutional Court Pl. ÚS 17/09 with no reference to EU law) and repeal of the 7-day time limit for actions brought in detention facilities and for inadmissible applications and time limits for a decision in the case of concurrence of asylum and expulsion proceedings (Act No. 303/2011 Coll., in force since 2012). Out of these amendments, only the changes made in 2005 , i. e. shortening of time limits and changes related to the suspensory effect of an appeal, were directly motivated by the Procedures Directive 2005/85/ES. In case of other amendments, the legislator did not mention the reason or referred to a general need for a more effective and faster procedure. Other important amendments were related to the overload of courts. Firstly, there were changes of territorial jurisdiction justified by the need to decrease the number of cases before the High Court of Prague, which was the only competent court at that time (Act No. 519/2002 Coll., in force since 2003). Secondly, the filter of inadmissible cassation complaints in asylum matters was introduced in 2005 in order to increase the effectiveness of procedure and decrease the overload of the Supreme Administrative Court in asylum matters (Act No. 350/2005 Coll., in force since 2005). Lastly, in 2015, there were a few changes related to the Act No. 314/2015 Coll., widening the list of decisions against which the appeal is deprived of the suspensory effect. This change was directly linked to a transposition of the recast of the Procedures Directive.

The overview indicates that most of the amendments linked to the review of asylum decisions were motivated by internal factors: the need to shorten the proceedings and to increase the effectiveness of proceedings for example on the grounds of an overload of a particular court (in case of territorial jurisdiction changes or in case of inadmissibility of the cassation complaint) that was not directly based in European Union law. In fact, the amendments linked directly to European Union law were the changes resulting from the need to transpose and implement the Procedures Directive and its recast (the influence of European Union law while introducing the direct access to the court in 2002 was rather indirect). This could lead us to the conclusion that the sys- 
tem of review in asylum law in the Czech Republic is influenced by European Union law only to a limited extent and the Member States maintain, while respecting the rather general obligation to provide an effective remedy, quite a large degree of autonomy without stronger interventions to the institutional architecture of administrative or judicial review.

Nonetheless, the latest development, i. e. the revised Procedures Directive and the proposal for Procedures Regulation, must be considered. The main amendment vis-à-vis the previous regulation of effective remedy is the requirement of a full and ex nunc examination of both facts and points of law and an examination of the international protection needs at least before a court or tribunal of first instance ${ }^{14}$. This was (and still is) the challenge also for the Czech legislator who opted not to amend the Asylum Act and maintained the judicial review based on the cassation principle as it complied (according to the rapporteur's opinion) to the procedural directive requirements. ${ }^{15}$ But even the explanatory memorandum mentions that the amendment of judicial review in asylum matters would be a legitimate and more appropriate option. ${ }^{16}$ Accordingly, a more radical change of the judicial review should be considered, because, despite the fact that the rapporteur claims full compliance with European Union legislation, such a conclusion is questionable.

The Czech judicial review in administrative matters is based on the principle of cassation, which means that the court cannot as a matter of a rule amend the administrative decision; it can only revoke the decision of the administrative authority ${ }^{17}$, as the administrative judicial review is limited to the revision in iure (revision of the lawfulness), therefore the court should not standardly review the factual findings ${ }^{18}$ of an administrative authority. The administrative judiciary, based on the principle of cassation, is not prepared and is not suitable for a full and ex nunc review. This is even more relevant for the area of asylum matters because providing a "full" review of both legal and factual findings requires extensive knowledge and language skills in order to search for the relevant, up-to-date and accurate country of origin information. Moreover, the need to examine the international protection needs might be interpreted as the need to grant international protection directly by the court (even if there are also opposite conclusions, see Reneman, 2015, p. 290), which is again not compatible with the cassation principle. This also poses a problem for other states, for example, the Slovak Republic that decided to refer the preliminary question to the Court of Justice. The Slovak Supreme Court asked whether Article 46 par. 3 must be interpreted to the effect that a national court deciding on the merits of an applicant's need for in-

14 See explanatory memorandum to the Directive 2013/32/EU that mentions in this respect the need to guarantee safeguards from article 47 of the Charter and the developing case law of the Court of Justice of the European Union and the European Court of Human Rights, especially concerning the right to an effective remedy. The reference to case-law is without any doubt the reference to the judgement of CJEU of 28 July 2011, C-69/10, Samba Diouf.

15 Governmental proposal of act, which amends asylum act, act on the residence of foreign nationals and several other acts, p. 105.

$16 \mathrm{lbid}$

17 See Article 78 of Act. 150/2002 Coll., Code of Administrative Justice.

18 See also judgment of the Supreme Administrative Court of 12 July 2007, No. 7 As 12/2007. 
ternational protection may, on the grounds that a negative decision has been repeatedly set aside and the case referred back to an administrative body on the basis of a repeatedly successful appeal, which has thus been shown to be ineffective, decide itself to grant such protection to the applicant, even if it does not have such competence under national law (C-133/17). The preliminary question related to the possibility (or obligation) of the court to directly grant the international protection was referred also by Bulgaria (C-585/16), Hungary (C-556/17) and the Netherlands (C-586/17), so the problems related to the different competitions of courts are evident not only in the Czech Republic. Until now, there are no answers from the Court of Justice, but the rulings should definitely be very interesting not only for the outcome, which will be crucial for the appeal system of the Czech Republic (and other affected Member States). The way the Court of Justice will try to balance the need to secure the existence of a truly effective remedy and the need to respect the procedural autonomy principle (and tradition of administrative procedures in different Member States) will be definitely of great interest as well.

The above-mentioned development reopens the debate about the possibility to establish a specialised asylum tribunal in the Czech Republic, whose creation has repeatedly been proposed instead of the review by general administrative courts ${ }^{19}$. This would make it possible to fulfil the requirement of a full and ex nunc review in asylum matters. Any other solution would be very problematic and incompatible with the overall systemic scheme of the administrative judiciary. Therefore, the creation of a specialised authority seems to be the most appropriate and effective solution. But even supposing the legislator would not come up with the systemic amendment, the interpretation of the current regulation in a way that would enable meeting the requirement of a full and ex nunc review would be an important interference to procedural rules currently in force. The need of a full and ex nunc review, as interpreted by Court of Justice so far, may not seem that revolutionary at first sight, however, it is definitely a very important interference to the system of judicial review of administrative decisions, although the full extent of such interference is not apparent yet. We cannot conclude that the wording of Article 46 par. 3 itself is a restriction to the procedural autonomy principle, because it is a result of the consensus of the Member States and it leaves upon the Member States how to reach the compliance with the obligation to provide the full and ex nunc review including the obligation to examine the international protection needs, however, its further interpretation could limit the scope of the procedural autonomy of the Member States.

\section{Legal Remedies in Czech Immigration Law}

European Union law influences not only the asylum procedures but also various aspects of other immigration procedures. Nonetheless, the scope of harmonisation differs and European Union law, in general, does not cover so many procedural aspects as in the asylum procedures. The move towards a

19 See for example Větrovský, 2006; Jurníková, Králová, 2016; Kryska 2016; Navrátil 2016. 
common procedure in the longer term was pronounced only in relation to the asylum procedure, not to immigration procedures in general. ${ }^{20}$ We will, therefore, focus on the type of procedures that are to some extent harmonised by European Union law, i. e. the visa procedures, the administrative expulsion, and the administrative detention procedures.

We can summarise the key amendments of Act No. 326/1999 Coll. on the Residence of Foreign Nationals in the Territory of the Czech Republic, related to the legal remedies as follows. Firstly, with respect to the visa procedures, there were three major changes (1) introduction of a specific appeal procedure for family members of EU nationals (Act No. 379/2007 Coll., in force since the end of 2007, a transposition of Directive 2004/38/EC in line with the interpretation given in the judgment of the CJEU C-503/03), (2) amendment of the appeal procedure and establishing of a partly independent Commission for decision-making in matters of residence of foreigners (Act No. 427/2010 Coll., in force since 2011, transposition of Art. 32 par. 3 of Regulation 4/2009 that requires to guarantee the right to appeal) and (3) introduction of a judicial review of visa decisions in case of family members of EU nationals (Act No. 427/2010 Coll., in force since 2011, transposition of Art. 31 par. 1 of Directive 2004/38/EC).

For administrative expulsion procedures, there were three major amendments: (1) repeal of an exclusion from the judicial review (made by Constitutional Court by decision from 9 December 2008, No Pl. ÚS 26/07 with no reference to EU law or CEJU case-law), (2) change of territorial jurisdiction and introduction of time limits to render the decision (Act No. 427/2010 Coll., in force since 2011, justified by the need to increase the efficiency, related to the requirements of Directive 2008/115/EC) and (3) introducing a longer time limit (10 days) to lodge an appeal against the administrative expulsion decision (Act No. 222/2017 Coll., in force since August 2017, no reason indicated).

Lastly, there were three important amendments related to the administrative detention procedures: (1) introducing the judicial review of lawfulness of detention and possibility to introduce a request for release to civil courts (Act No. 326/1999 Coll., in force since 2000, no reason indicated), (2) change of territorial jurisdiction and introducing time limits to render the decision (Act No. 427/2010 Coll, in force since 2011, justified by the need to increase the efficiency, related to the requirements of Directive 2008/115/EC) and (3) entrusting the judicial review of ongoing administrative decision to the administrative courts with stricter limits to render the decision (Act No. 303/2013, in force since 2014, amendment related to a private law reform - an opportunity to unify the administrative detention review).

The overview of the key amendments of appeal procedures for the aforementioned types of immigration procedures shows that the amendments are generally rarer than in case of asylum procedures (even if the amendments of Act No. 326/1999 Coll. are very frequent). It could also be concluded that the legislator remains rather autonomous as most of the amendments are not di-

20 See the presidency conclusions of Tampere European Council of 15-16 October 1999. 
rectly based in European Union law. The changes of appeal procedures in case of administrative expulsion and detention are influenced rather indirectly; the legislator uses the reference to European Union law as a supportive argument. The only exception is the visa procedure whose review was introduced as a direct consequence of an obligation stipulated by the visa code. Also in this case, we could argue that the procedural autonomy of state is maintained because European Union law regulates only the obligation to provide an effective remedy and the choice of particular procedural institutes stays within the discretion of the Member State, in compliance with the procedural autonomy principle. However, this does not seem to be completely accurate in the context of the interpretation of the effective judicial protection principle as provided by Article 47 of the Charter of Fundamental Rights of the EU.

European Commission in its Report on the Application of the EU Charter of Fundamental Rights for 2013 came to the conclusion that "the right to an effective remedy, enshrined in Article 47 of the Charter, requires that an appeal against a visa refusal, annulment or revocation, includes access to a judicial body, as only or last instance of appeal" (European Commission, 2013, p. 8). Subsequently, the European Commission sent formal letters to the Member States concerned (the Czech Republic, Estonia, Poland and Slovakia) urging them to take the necessary actions to ensure that appeals against a decision to refuse, annul or revoke a visa include an access to a judicial body (European Commission, 2014). Those infringement cases are still active, and until now the Commission decided to refer the Slovakia to the CJEU for not allowing judicial appeal against a decision to refuse, annul or revoke a visa. ${ }^{21}$ The example of a restriction to the procedural autonomy principle is quite striking as the Commission's interpretation of the "right to appeal" goes far beyond the consensus reached by the Member States who opted for a possibility of a non-judicial review. Martin Smolek even concluded that an extensive interpretation of Article 47 of the Charter serves in this case as a political tool in a battle for competence between the Member States and the European Union (Smolek, 2015). This opinion can, of course, be questioned, but the fact that such an interpretation represents an important restriction to the procedural autonomy principle of the Member State, even if it is motivated by a more effective legal protection, is indisputable.

In light of the above, recent judgment of the Court of Justice of 13 December 2017, C-403/16, El Hassani provides interesting (although limited) answers to the conflict between the procedural autonomy principle and the right to an effective remedy. The Court provided that Article 32(3) of the Visa Code, read in the light of Article 47 of the Charter, must be interpreted as requiring Member States to provide for an appeal procedure against decisions refusing visas, the procedural rules which are a matter for the legal order of each Member State in accordance with the principles of equivalence and effectiveness. These proceedings must, at a certain stage of the proceedings, guarantee a judicial appeal. The Court stressed that the European Union legislature left

21 See the database of infringement decisions available at <http://ec.europa.eu/atwork/ applying-eu-law/infringements-proceedings/infringement_decisions/?lang_code=en>. 
to the Member States the task of deciding the nature and specific conditions of the remedies available to visa applicants and that according to the settled case law, in the absence of European Union rules on the matter, it is up to the national legal order of each Member State to establish procedural rules for actions intended to safeguard the rights of individuals, in accordance with the principle of procedural autonomy, on the condition of respecting the principle of equivalence and effectiveness. And it is up to the referring court, which alone has the jurisdiction to interpret its national law, to determine whether and to what extent the review system at issue in the main proceedings satisfies those requirements (par. 25,26 and 31 of the judgment). However, Article 47 of the Charter requires the Member States to guarantee, at a certain stage of the proceedings, the possibility to bring the case concerning a final decision refusing a visa before a court (par. 41). By this judgment, the Court tried to have the cake and eat it too - the "right to appeal" does not equal the right to judicial review and it is up to the Member States (with respect to the principle of autonomy) how they will arrange the nature of appeal within their remedial systems. However, the Member States must still provide access to judicial review at some stage of the proceedings. This is the solution which will require amendments of the review of visa decisions in the Member States concerned; the outcome stays similar to the request of the Commission, but the Court used argumentation that does not give you the impression that the procedural autonomy of the Member States was ignored.

\section{Conclusions}

An overview of legislative amendments related to legal remedies in asylum and immigration law shows that the legislator maintains a certain degree of procedural autonomy while transposing and applying European Union law, even though the extent of European Union law constraints importantly differs for each subarea of asylum and immigration law. This can be seen mainly in the overview of amendments related to remedy in asylum procedures, with an exception of the newest development based on the recast of the Procedures Directive. It must be stressed that the procedural autonomy in this sense does not mean that the Member State is completely free from any European Union law constrains uncontrolled by the Court of Justice (Bobek, 2011 , p. 316). On the contrary, the margin of appreciation for the national legislator becomes narrower. As general advocate Villanon stated in the context of the asylum case of Samba Diouf, the Member States are obliged to organise the procedures in such a way that the procedural autonomy of the Member States does not create an obstacle to the effectiveness of the right to an effective remedy, ${ }^{22}$ whose interpretation broadens. This can be seen in the case of the "new" Asylum Procedures Directive and its approach to the scope of judicial review that must be "full and ex nunc" and on the interpretation of rights to an effective remedy in the context of visa procedures. Step by step, the principle of effective judicial protection starts to prevail upon the principle of procedural autonomy and the European Union Member States

22 Opinion of general advocate of 1 March 2011, C-69/11, Samba Diouf, par. 46-47. 
must adapt to an increasingly extensive interpretation of the effectiveness in the context of judicial protection. This new development could, therefore, question the conclusion of judge Prechal, that the procedural autonomy principle remains the leading principle governing the application of European Union law (Prechal, 2011, p. 31). Moreover, we should consider the fact that European Union law influences not only the remedy itself but also a lot of other procedural aspects determining the final form of the appellate procedure. Returning to the main research question, to what extent the European Union law influences the legal regulation of remedies in asylum and immigration law, we could very briefly summarize that the extent differs for each subarea of asylum and immigration law but in general, the scope of influence is widening (very often through the case law) and sometimes it comes as a surprise for the Member State (and not always as a pleasant one).

Even if the efforts of the European Union to provide the most effective legal protection possible should be appreciated, it is doubtful whether it is really possible to guarantee the effectiveness of legal protection by means of "forcing" the State to adopt solutions that do not have sufficient legal background in the national legislation and can therefore be isolated vis-à-vis national procedural rules. While opinions on the benefits and drawbacks of a more extensive interference with national procedural rules may differ, the national legislator should get used to broader restrictions to his margin of appreciation or "autonomy", because European Union is gradually approaching not only harmonised but also uniform asylum and visa procedures. And the same development can probably be expected also for other types of immigration law procedures. 


\section{References}

Baghrizabehi, D. (2016). The current state of national procedural autonomy: a principle in motion. InterEULawEast: journal for the international and European law, economics and market integrations, 3 (1), pp. 13-30.

Bobek, M. (2012). Why there is no principle of "procedural autonomy" of the Member States. In H. Micklitz and B. De Witte, eds., The European Court of Justice and autonomy of the Member States. Cambridge, Antwerpen, Portland: Intersentia, pp. 305-322.

Brouwer, E. (2007). Effective Remedies in Immigration and Asylum Procedures: A Matter of General Principles of EU Law. In A., Baldaccini, E. Guild and H. Toner, eds., Whose freedom, security and justice? EU immigration and asylum law and policy. Oxford, Portland: Hart Publishing, pp. 57-83.

European Commission (2014). October infringements package: main decision. At <http://europa.eu/rapid/press-release_MEMO-14-589_en.htm>, accessed 12 March 2018.

European Commission (2013). Report of European Commission on the Application of the EU Charter of Fundamental Rights. At <https:// publications.europa.eu/en/publication-detail/-/publication/1f1d1bcd-af5a4028-8745-341c66e83b99>, accessed 12 March 2018.

Jurníková, J. and Králová, A. (2016). Komu svěřit posuzování a přezkum žádostí o mezinárodní ochranu? Časopis pro právní vědu a praxi, 24 (2), pp. 131-141.

Kryska, D. (2016). Právo na účinný právní prostředek nápravy ve věcech mezinárodní ochrany a české správní soudnictví. In: J. Jurníková and A. Králová, eds., Společný azyový systém v kontextu uprchlické krize. Brno: Masarykova univerzita, pp. 99-122.

Prechal, S. (2011). Redefining the Relationship between 'Rewe-effectiveness' and Effective Judicial Protection. Review of European Administrative Law, 4 (2), pp. 31-50.

Navrátil, P. Transpozice čl. 46 odst. 3 tzv. procedurální směrnice do právního řádu ČR: šance pro strukturální reformu správního soudnictví (2016). L. Pítrová, ed., Aktuální právní aspekty migrace. Praha: Leges, pp. 126-140.

Reneman, M. (2014). EU asylum procedures and the right to an effective remedy. Oxford: Hart Publishing.

Smolek, M. (2015) Přinesla Listina EU (cokoli) nového? (n. d.). At < http:// jinepravo.blogspot.cz/2015/03/martin-smolek-prinesla-listina-eu.html>, accessed 10 March 2018.

Safjan, M. (2014). A Union of Effective Judicial Protection. Addressing a multilevel challenge through the lens of Article CFREU. At <https://www.kcl.ac.uk/ law/research/centres/european/Speech-KINGS-COLLEGE.pdf>, accessed 12 March 2018.

Smolek, M. (2015). Přinesla Listina EU (cokoli) nového? At <http://jinepravo. blogspot.cz/2015/03/martin-smolek-prinesla-listina-eu.html>, accessed 12 March 2018.

Větrovský, J. (2006). Výhody a nevýhody přezkumu rozhodnutí ve věcech azylu soudy v rámci správního soudnictví. In: D. Jílek, D., ed., Společný evropský azylový systém: procedurální směrnice. Brno: Masarykova univerzita, pp. 83-103. 